\title{
Modes of Understanding of the Religion "Object" in North Atlantic Modernity
}

\author{
Stewart M. Hoover \\ Center for Media, Religion and Culture, University of Colorado at Boulder \\ 1511 University Avenue, 0478 U св, Boulder, Colorado, 80309-0478, USA \\ hoover@colorado.edu
}

\begin{abstract}
Recent struggles over the implications of migration have fueled transformational politics on both sides of the Atlantic. At the center of this are questions of identity, value, long-standing standards of human rights and even enlightenment categories of modernity. Both religion and media play central - even determinative - roles in these debates. This article will argue that scholarships focused on identity "imaginaries" are critical to understanding these discourses and this politics. This scholarship must inquire into both "sides" of migration, both the conceptual worlds of those who wish to move, and the conceptual worlds of those who receive (or attempt to not receive) them. This article will look at the latter through a deep historicist inquiry into the mediation of Protestantism as a central determinative force in the establishment of contemporary conditions of politics in relation to migration in the North Atlantic West. Protestantism's role in European modernity is well-known, as is its deep interconnection with evolving technologies and means of communication and practices of mediation. This article seeks to understand religion-inflected discourses of nationalism and identity as functions of Protestant social and media instrumentality.
\end{abstract}

\section{Keywords}

media - politics - imaginaries - religion - populism - nationalisms 
The events of 2016 and afterward in North Atlantic politics have substantially unsettled things that were once taken for granted. Not least, the post-war European order and its complex inter-connection with the project of United States foreign policy was seriously destabilized by the British "Brexit" vote, election victories by nationalist and right-wing parties, and by the election of Donald Trump. These seemed to foreshadow further change, as the effects of a new political order may be finding their way into the local and national politics across Europe and North America.

There have been many efforts to explain this new era. The most common narrative attributes the new politics to the maturing of neo-liberal globalization with its impacts on national and regional markets, trade, and labor. This suggests that the critical incident was the 2008-09 recession, which was enabled by globalization's interconnecting systems of finance, and which was felt unevenly across the developed and developing worlds and markets. Among the direct results were increasing public distrust of the political and economic structures that typify modern liberal capitalism and a surge in the global flows of populations, including both economic and political migrants. Simply put, 2008-09 led to greater feelings of vulnerability and instability, and political movements that claimed to address these feelings by focusing on the flows of population through asylum and immigration, began to gain strength.

What has emerged is a complex and diffuse political discourse that has begun to gather strength across national contexts, and which draws together themes of grievance, mistrust, and resistance. Often called the "new populism," these forces are far from unified in their contexts and material circumstances. But, at the same time, there are some striking similarities between them, similarities that are best understood not in terms of their sources in social structures or established institutions of state, nation, or religion, but rather in the more subtle - and at the same time more profound - terms of collective imagination. They are contemporary imaginaries, of the kind described in recent work by Alma and Vanheejswijck ${ }^{1}$ as containing secular, religious, political, and economic imaginaries within them. As Alma and Vanheejswijck suggest, imaginaries must be understood to operate outside received and stable categories of identity, politics, and value. That is what I wish to explore here, while at the same time accounting for the ways that they are deeply articulated into systems of media circulation and practice. I intend my argument to extend thinking about imaginaries by investigating the historiographies and the

1 Alma/Vanheeswijck 2018, p. 3. 
implications of the ways that they are a direct consequence of modern means of communication.

To anticipate my argument, I want to root this exploration in a number of relevant discourses and literatures. First, the field of cultural studies, which intends to understand how cultural articulations such as those that undergird contemporary imaginaries function but do so at some distance from the actually-existing realities "on the ground." Second, the field of religious studies, which has gradually broken free of its original provenance in essentialist, orientalist, and colonialist ideas about the nature of the religion "object." We can now understand religion in terms of its materialities and its practices, not just its theologies and normative claims. Third, the fields that surround contemporary media studies, which have largely failed to articulate a substantive scholarship of religion, choosing instead to see religion and media in binary terms and the essential questions to be those of their effects on one another. Finally, the fields that are attempting to interpret contemporary North Atlantic politics, particularly those related to political science, which have seen relations between religion, media, and politics primarily in essentialisms and epistemologies of power and institutional authority. My project here is to unpack these various provenances, mining them for meaningful clues as to the actually-existing influences and practices that constitute contemporary politics along the boundaries between religion and secularity.

\section{Defining a Politics of the Times}

To think of politics in terms of media imaginaries challenges much of our received wisdom about the nature of politics. We want to think of politics in terms of concrete and material "interests." Indeed, politicians typically articulate themselves to specific class, economic, and community interests. The contemporary situation, however, challenges us to think differently about the sources of politics. It opens up the possibility that the fortunes of states can be linked not to their success in the provision of national security, economic well-being, and social peace, but to the way they are thought about. We have long known - and broadly accepted - Benedict Anderson's ${ }^{2}$ basic premise of the power and force of imagination. The dimensions of his view that are most pertinent here are the implication that imaginaries are diffuse and grounded outside the realm of material interests and are deeply and at the same time uniquely powerful and convincing. It has been suggested, of course, that

2 Anderson 1991. 
nationalism and nations are more understandable as conceptual than as material geographies. This was foundational in the earliest work on nations and nationalism such as Carlton Hayes's Essays on Nationalism. In her account of the history of nationalisms, Greenfield ${ }^{3}$ describes how the very idea of nationalism arose in relation to nations and states as a way of explaining and legitimating them. Anthony Smith ${ }^{4}$ has further refined this premise in his work focusing on the ways that nations and nationalism depend on conceptual frames that are religious in form and character. I will return to religion in more detail presently, but I would like to set one premise for my explorations here that is rooted not in history, philosophy, or political science, but in the field of cultural studies.

My purpose here is to chart a way through the complexities of the current moment that looks at the ways imaginaries of the nation and national identity are increasingly articulated through and into contemporary social and political discourses that flow above and beyond actually-existing nations but nonetheless powerfully affect their political prospects. I hope to describe ways that these imaginaries are functions of - and help form - emerging forms of religion and secularity. But, the insight I want to bring from cultural studies is the idea that the very distance between the actually-existing conditions of religions, nations and states and the aspirations articulated in imaginaries of nation is itself a powerful force driving the latter process. The work of cultural scholars such as Stuart Hall in relation to politics calls on us to consider the cultural "work" that is called into being by such distances.

We must remember that our lenses of knowledge and interpretation are themselves always tentative and partial. For those of us who are scholars, this partiality is rooted in deeply complex and well-trod paths of intellectual inquiry. The ways we know and understand the world are based on conceptual maps which are particular and conditional. Recent encounters with emerging discourses which re-think the provenance of Western intellectual history, such as those in the current, substantive discourses in decoloniality 5 , provide us with valuable cautions about the epistemic reach of our attempts at description and understanding.

3 Greenfield 1992.

4 Smith 2004.

5 Mignolo 2011. 
We must thus come to terms with the tools we have. The point is not to focus on their limitations, but to understand the things they can and cannot do for us. The particular field of analysis I address here is one that has been, and remains, particularly riven with conceptual and theoretical challenges to understanding. This is true in each of the broad scholarly areas that are relevant to an understanding of the contemporary moment. Fields that address religion and those that address media have suffered from significant lacunae not least in relation to how each of them thinks about the other. Anthropology and political science, among the fields that have been influenced by Anderson's work on imagination, have been likewise challenged.

My approach here is to consider the significant analytical turns that might be necessary to explain the circulation and construction of imaginaries of religion in the contemporary social and political moment. As we contemplate a time when religion is more and more present in social and political discourse in the North Atlantic West, it seems less and less like the "religion" of old. Most fundamentally, it lacks the older institutional frames and modes of authority that defined religion in the past. It is no longer constituted by doctrine or faith or confession, but circulates beyond and above these things. This new character of religion is obvious when we think about the simple facts of contemporary North Atlantic politics. When compared along traditional lines, there are marked differences between religiosity in the United States and in Western Europe. Yet in both contexts, there are emergent nationalist political forces that evoke "the religious" in similar ways. This means we need to find new ways of understanding and accounting for religion - and secularity - in contemporary history.

It goes without saying, perhaps, that this situation with religion/secularity is possible to a great extent because of an emergent role for Andersonian imagination and imaginaries. Religions can play a role in contemporary politics in the way they do because they can be invoked in social and political imaginaries in ways that strip them down to particular "essentials." They become "free-floating signifiers" to exquisite performative extents Levi-Strauss never could have predicted. In contemporary discourses, they are crafted and woven into complex visual and linguistic arguments and become increasingly politically significant ${ }^{6}$. This directly challenges some of our most deeply-ingrained

6 Brubaker 2012. 
assumptions in the Western academy. In both academic and lay discourse, it has long been thought that only institutional or structural attributes matter in religion or in politics ${ }^{7}$. To begin to think about things in terms of imagination takes some careful re-thinking ${ }^{8}$. It is thought that structural and institutional attributes speak directly to "interests." It is a bit of a stretch to begin thinking that imaginaries of value and aspiration can also be "interests" and similarly motivate social action and politics.

An even more important conceptual turn would take into account the central context where this discursive production is taking place. Much of this is possible today because of the existence of modern structures, systems, and traditions of communication. The role of digital media in recent elections is well-known. Various state and non-state actors have used social media to interfere in them both in the U.S. and in Europe ${ }^{9}$. Social media circulations have also helped form networks and communities of shared interest that transcend traditional national and regional boundaries. But the role of the media in these relations is not limited to social media alone. The social media revolution was made possible by - indeed is still dependent on - a broader, longerterm structure of public mediation that has come to define modern life to a great degree ${ }^{10}$.

The definitive nature of media in contemporary life cannot be over-stated. Across most major categories of life, media increasingly define the terms, frameworks, and contexts whereby institutional action takes place ${ }^{11}$. The idea that we live in a "media age" is so banal that it is almost not worth saying. Except that the extents and limits of the media in relation to society, culture, politics, and religion remain inadequately understood. This is a problem that transcends disciplinary boundaries, but is one that - in relation to questions of the mediation of religion at least - is beginning to be addressed by new scholarly frontiers, as I will discuss presently. The inadequacy of our frameworks for understanding contemporary media and society is illustrated by the wide range of ways media are thought and talked about. Media are described as both trivial and powerful. They are understood primarily by their content in some contexts and by their structures in others. They are seen as instrumentalities of social or cultural change, or mere reflections of the culture.

Friedland 2002.

Alma/Vanheeswijck 2018.

Birnbaum/Timberg 2019.

Hjarvard 2008; Couldry 2012.

Hjarvard 2008. 
This a problem for the project I am outlining here because the processes and practices of imagination in relation to contemporary culture and politics are largely mediated. That is, they are articulated into - or understood primarily in relation to - media circulations, structures, and texts. The free floating signifiers of contemporary religion float through a technical and practical structure that has been centuries in the making and now exists in a place of tacit, banal power at the foundation of contemporary discourse: "the media."

\section{$5 \quad$ Charting a New Course}

To move ahead then, this project must begin with a series of re-thinkings. First, a re-thinking about the nature of contemporary religion. Second, a re-thinking about systems and practices of mediation, and finally, an account of the way that imaginaries of social and political value today flow through mediatic imaginaries of "the religious" and "the secular." The very indefinition of these relations - their "free-floating" nature, also means that "the religious" and "the secular" are no longer a binary. They are no longer irreducible contradictions. Instead (as we will see) imaginative circulations of religion today involve negotiations and contestations between ideas of religion and secularity.

I hope to introduce and support the idea that a particular way of looking at and thinking about contemporary religion is necessary to the broader task. That is an approach which understands religion through its mediations. Traditional and received ways of accounting for religion have tended to focus on essentialist definitions. In North Atlantic high modernity from the early modern period onward, religion came to be understood this way. In fact, as Asad has argued ${ }^{12}$, the very category of "religion" per se is an artefact of this period. Others have likewise pointed out the limitations of essentialisms. They are bound by their times, belie a "Protestant" bias about the nature of religion, and have come under increasing scrutiny from contemporary colonial and decolonial critiques ${ }^{13}$. Thus, our essentialist views of religion are bound by their sources in enlightenment history.

Among the things these received views overlook is the extent to which religions are not only contained in their doctrines, texts or lines of clerical authority. They are also contained in the practices and expressive materialities through which they are ritualized, celebrated, known, and circulated. This approach to religion is of course a "turn" that scholarship in the field of

\footnotetext{
12 Asad 1993 [1982].

13 Nyamnjoh 2017.
} 
religion took over two decades ago ${ }^{14}$. This turn toward practice and materiality emerged, as Warner ${ }^{15}$ notes, from the concrete empirical experience of field research as it encountered a shifting and evolving religious landscape.

\section{From Binary to Articulated Understandings of Media and Religion}

In order to understand some crucial things about contemporary religion, we need to understand the role of formative imaginaries in it. This requires a new kind of scholarship, one that is rooted in evolving discourses in areas such as research on religious imagination, critical reflections from post-colonial and decoloniality literatures, and - importantly - evolving research into the nature of contemporary mediated religion. I would like to suggest that the turns toward materiality and practice were not merely discoveries of new modes of analysis (though they were). It might be argued that they were also responses to new modes of emergent religious practice ${ }^{16}$. My project here is rooted in the notion that these new modes represented a gradual articulation of "the religious" with emerging means - largely mass-mediated means - of "doing religion."

To say this is also to challenge a traditional "binary" view of media and religion. By "binary" I mean to point to the facile assumption that media and religion are separate spheres, and that the goal of scholarship must necessarily be an analysis of the "effects" of one upon the other. I have elsewhere discussed this matter in some detail ${ }^{17}$, and others have also suggested that it is time to think about media and religion in terms of their integration, rather than as a formation of binaries. The facts of this situation are obvious empirically ${ }^{18}$. In an influential essay, Jeremy Stolow ${ }^{19}$ laid out an argument for thinking of "media as religion." By this he meant not that the media have come to replace religion, but that media circulations are foundational contexts where religion is understood, articulated, and practiced today.

Evidence of $[\ldots]$ a tight weave between religion and media can readily be found, not only at the level of practice among actually existing institutions and communities of faith (and, of course, their corresponding

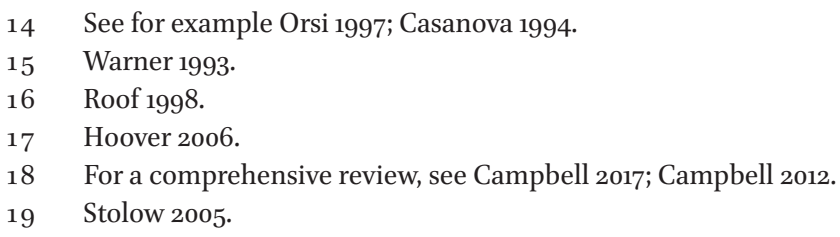


market segments), but also at the level of broader, cultural constructions haunted by 'religious' imagery and figures of discourse, including current notions of transnational belonging and multicultural citizenship, tolerance and intolerance, universality and difference, hospitality and war, or faith and credit. ${ }^{20}$

Stolow argues that the tendency to think of media and religion in binary terms belies an underlying commitment to an unrefined definition of secularization in modernity. He joins others ${ }^{21}$ in calling for a view of secularization and secularity that does not disembed religion and banish it to the private sphere. This articulation of religion and mediation in modernity, what Stolow called the "tight weave," suggests an important shift in perspective on the part of scholars of contemporary social and political life. At the most basic level, it suggests that "media" and "religion" should no longer be thought of as separate dimensions of social processes, but that there must be analytical room for seeing them together. This is what I wish to point to by suggesting we understand them as "articulated" with one another.

I mean to use the term "articulation" in the sense of that term invoked by the late Cultural Studies scholar Stuart Hall, as

$[\ldots]$ the form of the connection that can make a unity of two different elements, under certain conditions. It is a linkage which is not necessary, determined, absolute and essential for all time. ${ }^{22}$

This formulation avoids what might seem obvious on the surface, that relations between "religion" and "media" might simply be described in terms of the mediation or mediatization of religion. This is intentional in my argument. While it goes without saying that modern means of communication have come to assume roles of representation, pedagogy, symbolic formation, etc., from more archaic means (that is, they are the "modern" forms of these things), and thus it is necessarily the case that contemporary media do "mediate" religion, I want to hold onto a different way of thinking about media in these regards. This is because "the media" as we know them today are not best thought of merely as means of communication. Stolow makes a similar point when he suggests,

\footnotetext{
20 Stolow 2005, p. 123.

21 See, for example, Calhoun/Jurgensmeyer/van Antwerpen 2011.

22 Morley/Chen 1996, p. 115.
} 
I would like to propose that the least fruitful work consists of studies that simply seek to trace the various ways religious adherents, leaders and movement activists either 'succeed' or 'fail' to transmit religious messages through the strategic control of the material communicational resources required for self-confirmation ('preaching to the converted'), or to perform the work of outreach, proselytism and related forms of social mobilization. ${ }^{23}$

What Stolow (and I) wish to question is the tendency to think of media instrumentally. The scholarly fields that undergird contemporary media studies evidence a decades-long re-thinking and re-positioning of the "media object" away from this banal instrumentalism. These discourses, which have addressed both theoretical and methodological issues, have opened the conceptual door to broader and more complex ways of understanding the media in late modernity. While it is commonplace (and in a way quite human) to think of media as "communication" and their location in social and cultural processes primarily as conduits of action that originates and terminates elsewhere, we have come to understand that the media are much more than instrumental channels of language, culture, symbol or influence. They are, in fact, articulated into the locations of materiality and practice where they are active. As I hope will be obvious, describing media in these terms makes possible more substantive and meaningful accounts of how imagination and imaginaries might work in relation to contemporary religious politics.

Media and Religion in Late Modernity

While it is beyond the scope of this discussion to provide a detailed account, the relations between religion and media from early to late modernity in the North Atlantic West is both illustrative and probative for the case I wish to address here. I am saying that media and religion are "articulated" in historic terms, and that that history is best understood as a particular rather than a general history of the mediation of religion. The media sphere that we have inherited in the developed North is a creation of the interaction (again the "articulation") of "religion" and "media." The history is actually well-known, while the project of describing the articulation of media and religion in modernity is not.

23 Stolow 2005, p. 124. 
Most accounts of the history begin with the Reformation, and the role of emerging cultures and systems of print production and circulation in it. Luther was an active producer of print materials, and his unique vernacular production was essential to the dynamic spread of Protestant ideas. His relationship to Lucas Cranach the Elder is also part of the received account. Print, literacy, and religious revolution flowed together in 16th Century Europe. But a full account of the history carries within it clues to how media (in this case print) were more than just passive conduits of Lutheran theology. Emerging systems and practices of mediation articulated with the Lutheran project in ways that were greater than the sum of the two "parts:" the Reformation, and print culture.

In her definitive history of the print revolution, Elizabeth Eisenstein ${ }^{24}$ makes it clear that the effects of printing were not merely in the widespread circulation of print materials or of literacy, but were more profoundly based in the creation - through printing - of an entirely new social or cultural force: the publisher. Printing led to a political economy of publication, and printers became "publishers," social actors who - through their work in the new commodity culture of printing - established their own sources of power through capital. They were thus the source of the extensive institutional deployment that we today know and think of as "the media." Cranach the Elder was a pioneer in this, using his print business to establish both a context of voice for Luther, but also a system and network of circulation through which Luther became commodified. As one recent journalistic account of this history put it, "Long before twitter, Martin Luther was a media pioneer"25. Luther's media project was given an exponential boost by Cranach's creative and marketing skills. Cranach's media circulation was as much about the myth (or "imaginary") of Luther as it was about his theology. The Luther/Cranach partnership created and exploited an emerging media form - the pamphlet - which was made possible by the technologies of print, and then became a new "medium" as it were, creating markets for vernacular circulation that had not existed before.

The articulation of vernacular print material with the Protestant project was thus both intellectual/conceptual and practical. Yes, these circulations pushed Lutheran ideas to new intellectual and geographic locations. But because they were necessarily mass-produced and widely distributed (and thus represented new, commodified and market-driven ways of circulating religious ideas), they materialized through practice the lived notion of more

24 Eisenstein 1978.

25 Mohn 2016. 
popular or vernacular religion. It wasn't just Luther's ideas, it was also the ways those ideas were materialized. With apologies to McLuhan, the medium was the message.

In a larger project currently in progress, I am developing an account of how relations between Protestantism and media continued to develop across the early modern period and beyond. There is a good deal more to be done to fill in this history, but for my purposes here we can zoom ahead rather quickly to the English colonization of the North American continent, and pick up the narrative of Protestantism and media there and then. In this colonial history we still see a formative articulation between systems and practices of media and the specific Protestant project of colonization.

\section{The Particular Case of Protestantism and Media}

In an influential work, literary historian Tracey Fessenden ${ }^{26}$ describes how the early Puritan fathers (the clerical establishment in the American colonial period) negotiated a place for their authority in the evolving context of a rapidlydeveloping and diversifying nation. Historian of American Protestantism David Hollinger ${ }^{27}$ argues that, in the American context at least, the challenge of diversity became definitive for Protestant authority. The original conception of the American project was one of an exceptionalist ${ }^{28}$ opportunity to shape the new nation as a "city on the hill" where Puritan/Protestant culture would demonstrate to the world its unique abilities to form, shape, and bless this open, virgin territory (a project that involved, of course, genocide of the land's original inhabitants). Hollinger argues that this view was substantially challenged by later waves of immigration to the American colonies, Jews and Catholics in particular.

Fessenden shows how the challenge of diversity was seen by Protestant authority largely as a problem of communication and of reforming and reshaping the communicational public sphere. These leaders controlled, to a great extent, the media in the form of print publishing, and further understood

\footnotetext{
$26 \quad$ Fessenden 2006.

27 Hollinger 2013.

28 "Exceptionalism" or "American exceptionalism" refers to a long-standing doctrine in American public culture and civil religion which holds the increasingly controversial view that the American project was somehow ordained to a high purpose by a divine order. It traces its roots to Puritan preaching in the colonial period, but has been articulated much more recently in American political discourse, most notably by President Ronald Reagan. For a recent review, see Hoover 2014.
} 
that the fundamental task would involve asserting Protestant hegemony over the American public sphere. The confrontation between settled Protestant authority and immigrant Catholicism was engaged in terms of the means of communication. The important learning relevant to my project here is that, by the time of the American colonial period, some two hundred years after Luther, Protestantism and media were already articulated with one another in very fundamental ways. And - significant to my project here - the definitive condition then, as now, was the challenge of migrations, boundaries, and cultural diversity.

It is significant and important that this example comes from the American case. I don't intend to generalize the American history here. Instead, I want very much to argue that the American experience of Protestantism and media constitutes a powerful explanatory historiography. Among the things we can draw from it is that it can help explain how contemporary relations between religion and media can afford the imaginaries of politics between religion and secularity which are the object of my efforts here. The American case is, I would argue, a central case not least because of the centrality of American media technologies, systems, and structures in the global media sphere. It is also a central case because of the particular ways that American religion specifically Protestantism - has deployed media and practices of mediation across its national history. The Lutheran media legacy in Protestantism has found expression in American religious institutions and movements which have been nearly uniquely wedded to emerging means and technologies of communication.

This articulation of Protestantism with media has had implications well beyond the religious sphere. Indeed, tacit Protestant cultural hegemony has expressed itself directly through such things as the regulation of American media content. The Hollywood production code by which American motion pictures have been "rated" as to content, for example, was heavily influenced by Protestant leaders and laity. What came define mainstream American values in media were in fact Protestant values ${ }^{29}$. To the extent that American media forms came to international cultural hegemony across the 2oth Century (and they did) it was then the case that these American forms, again derived from the interaction between Protestants and American public culture, have had an important international reach as well.

This articulation between Protestantism and media always has seemingly contradictory sides to it, however. On the one hand, Protestants have been powerfully attracted to each new emerging form of popular communication,

29 Romanowski 2012. 
seeing these forms as wonderful opportunities for influence and outreach ${ }^{30}$. On the other hand, Protestants have sought to be active in relation to what they have seen as the dangers of media and mediated culture. Between these two visions of media and culture, Protestant authority has sought to maintain a position of cultural hegemony, as described in the American context by Digby Balzell's classic work on the Protestant establishment ${ }^{31}$. Balzell's thesis points to an establishment that exercises its authority largely tacitly. Fessenden's history shows how this tacit yet powerful social position resulted from strategic action taken by Protestant leaders who saw practices of communication and mediation as the way to achieve their goals of subtle, implicit cultural power. Further, in the Protestant imagination, media and processes of communication were seen as particularly important and effective means of instrumentalizing religious purpose, towards both "religious" and "secular" ends.

My point is that in the case of American Protestantism, the linkages between media and religion show a significant articulation that has seen each significantly shaped by the other. Media producers have, across most of the 2oth Century, consciously modulated their productions to the sensibilities of Protestant taste cultures, and in response to the pressures brought to bear by Protestant leaders. At the same time, Protestant practice has become effectively interlinked with media practice, as developing and emerging systems of media circulation have privileged ways of extending the reach of religion that are most consistent with media and mediation.

This was most obvious in the emergence in the 1980 os of forms of religious mediation known as "televangelism." New media-based Protestant ministries emerged to take advantage of advances in television production and transmission ${ }^{32}$. These ministries produced programming that was consciously articulated to the standards and forms of television at the time. They looked "sophisticated" in media terms. Part of their sophistication, of course, were their conscious strategies to accommodate themselves to the television "form" in order to attract large audiences ${ }^{33}$. This meant that they often had to make concessions to the formal constraints of television broadcasting, believing that the benefits of doing so outweighed the costs. These ministries faded in importance later in the 2oth Century, but a number of them persist today.

Several consequences of this history stand out. First, for American Protestants (and for Protestants elsewhere due to the influence of the

$30 \quad$ Hoover 1987; Hendershot 2004.

$31 \quad$ Balzell 1987.

32 Hoover 1987; Horsfield 1984.

33 Hoover 1987. 
American model) media and mediation are now commonly understood to be appropriate, even enchanted extensions of Christian purpose. There is little if any residual suspicion of media and media forms, particularly in conservative and evangelical circles. Second, religiously-motivated media creators and producers are experienced and sophisticated practitioners of their craft. Third, religiously-motivated media audiences are acclimated to the idea that media can be sources of profound truth and insight - that they can do the "business" of religion be it focused on confession and faith or on political or social activism. Fourth, this kind of religious media practice has also served to develop important networks of influence and circulation. Thus, in some ways, it is nearly impossible to describe a hermetic sphere within which unmediated religion (at least conservative religion) exists as a kind of pure form. No, religion today must contend with the reality that to exist, it must exist in - or with reference to - the media. And the particular history which has determined the outlines of this situation is a traceable Protestant history that flows through North American Protestantism and its articulation with media.

\section{Mediated and Imagined Religious Nationalisms}

The forces which have motivated my inquiry here seem on their face to contain several contradictions. Most importantly, much of the political momentum behind the new populism in the nations of the North Atlantic West seems not to flow directly from bases in classic material or class "interests ${ }^{34}$." Equally interesting is the tendency for these movements to appeal to religion secondarily. They are not primarily religious movements, but instead use religion more rhetorically or strategically. An example of the latter phenomenon is the way that right-wing forces in France responded to the tragic fire at Notre Dame in April of 2019. While some Catholic leaders celebrated the possibility that the incident would perhaps bring the faithful back to Church, voices in populist politics used the incident in a different way. They saw it as an opportunity to use religion to pursue their broader goals in political mobilization and boundary-building. One account quoted Jordan Bardella, the leader of France's National Rally party (formerly the National Front).

"In this context of ambient Christianophobia, do we [not] have the right to question the causes of the fire of \#NotreDame?" he tweeted on Saturday, connecting the apparent accident to recent incidents of church 
vandalism some politicians blamed on "militant secularism." That day he also gave a speech in which he said it was time to "stop this dictatorship of minorities that ruins the life of the silent majority." National Rally, which took a narrow lead in some election polls over the Easter weekend, has used rhetoric of secularism to justify banning the veil and other public expressions of Islam, including once organizing a protest of Muslims who were praying in the street because their mosque had been shuttered. Bardella proudly broadcast his faith on Sunday, tweeting, "What is happening in our country and around the world has at least one virtue: restoring meaning and vigor to our age-old traditions and to our Christian heritage. Happy Easter celebrations to all!"35

This illustrates well the contradiction I spoke of. National Rally is religious only to the extent that it sees religion as a way of framing nation in relation to the inroads it fears Islam is making into French society. When confronting Muslim dress, the party is happy to use the language of secularism. But it is also happy to use an event like the Notre Dame fire to inscribe a bright, imagined boundary between France and "others." Is it a religious or a secular movement? Perhaps that is not the question because in contemporary flows of religion and secularity the boundaries between the two are more and more difficult to inscribe. There is a sense in which, in public discourse, the religious and the secular co-exist and - in terms of politics - are negotiated and renegotiated conditionally and strategically.

It remains, though, that the fungible boundary between religion and secularity in relation to Notre Dame - and in relation to a range of other contemporary political issues - fits into the broad category of religious nationalism. Sociological literature on religious nationalism provides important and helpful insights into the issues I am considering here. In recent work, Brubaker ${ }^{36}$ has outlined what he describes as four ways of understanding religious nationalism. They are:

1) Religion and nationalism as analogous phenomena. This suggests that what is religiously significant about nationalism is merely the ways in

35 Feder/Maplestone 2019.

36 Brubaker 2012. 
which nationalism resembles religion, or the extent to which nationalism has become a religion.

2) Religion as a source of nationalism. This rejects the idea that, with religious decline, nationalism has arisen to replace it. Instead, religion continues to provide important explanatory and other power to nationalist interests and formations.

3) Religion as imbricated or intertwined with nationalism. This suggests that religion and nationalism are so inter-connected that we cannot understand one without the other. Religion is part of the phenomenon, rather than a mere explanation or model for it.

4) Religious nationalism is a distinctive kind of nationalism. In this case, religion forms the base and fabric of the possibility of nation, providing normative models of structure and authority.

Thus nationalism's invocation of religion can be seen to be possible in a number of forms, and Brubaker presents evidence and examples of each. He makes an important point, though, that it is important not to lose sight of the extent to which the purpose or object of nationalism is the nation, even when that nationalism is intertwined with religion:

Moreover, nationalist politics - based on claims made in the name of 'the nation' - remain distinct from (even as they are intertwined with) forms of religious politics that seek to transform public life not in the name of the nation, but in the name of God. To be sure [...] nationalism and religion are often deeply intertwined; political actors may make claims both in the name of the nation and in the name of God. Nationalist politics can accommodate the claims of religion, and nationalist rhetoric often deploys religious language, imagery and symbolism. Similarly, religion can accommodate the claims of the nation-state, and religious movements can deploy nationalist language. ${ }^{37}$

This describes well the complex relations that stimulated my exploration here. If our goal is to understand how political imaginaries today position themselves between religion and secularity in a project of focusing political energies toward new populist politics, then we must refine our analytical tools to be able to account for how religion and secularity can be negotiated into and out of these relations and discourses. The cases of interest are then those that reside in the second of Brubaker's categories, where religion provides motivation, language, symbols, and tools to nationalist efforts. Brubaker's taxonomy 
provides a further analytical tool in that it can describe situations where religion's role in nationalism moves beyond (or is intended to move beyond) a simple discursive deployment for definitional reasons. For example, there clearly are forces who aspire to create distinctively religious nations. However, religion can be involved in nationalist causes in other ways.

Is there more we can say about the logics of religiously-inflected nationalism even as we suggest that relations between religion and nationalism are strategic and conditional? Friedland has suggested that there is an inherent, coherent logic to religious nationalisms, and that we can see ways in which religion is an active constructor of nationalist formulations and rhetorics. $\mathrm{He}$ begins by suggesting that to understand the logics of religious nationalism we must move beyond arguments about material interests.

Religious nationalism must be understood in terms of its own cultural premises, not simply as a mediation of forces from elsewhere, as a sublimate of economic grievance or a carrier of group identity, as a medium for old class politics or new identity politics. ${ }^{38}$

Instead, we must try to understand it according to its own logics. Those logics are, in Friedland's view, best understood as an institutional project. By this he means that religious nationalism must be understood as a kind of singularity that derives its meaning and momentum from shared practices that are rooted in a set of guiding ontologies. Religious nationalism thus has a logic or set of logics. It is not a diffuse or incoherent or conditional phenomenon that shifts its basic forms to fit with particular contexts for political claims. Instead, it has a substance.

Friedland's work is notable for his exhaustive review of religious nationalisms from which he derives a description of their fundamental shared logics. It is important to note that Friedland's description is derived from empirical observation of nationalist movements. He describes them this way:

A specific chain of four elements can be found in the symbolic order of all contemporary religious nationalisms. First, religious nationalism configures the territorial collectivity as a sacred space and a divinely invested subject. Religious nationalisms all focus on the penetration and permeability of the boundaries of that territorial space, whether by foreign investment, civil or foreign war, immigration, or a global commodified culture. The defense of the integrity of the territorial space, as in all 
nationalist projects, is the medium through which the coherence, identity, and power of the collective subject is known and narrated. In every case of religious nationalism, there is an acute sense that that boundedness is at risk. Second, religious nationalists direct the bulk of their attention to the bodies of women - covering, separating, and regulating their erotic flesh. Third, religious nationalists accord considerable symbolic importance to money, to foreign money, to money out of control. And fourth, religious nationalists submit lovingly to God..$^{39}$

There are important echoes of this formulation in the symbolic circulations of contemporary populisms. But my point here is not to legitimate these movements and forces as nationalisms. Rather, it is to suggest, following Friedland, that there is a certain stable constitution to their claims, aspirations, and rhetorics. That is, that religious nationalisms can be understood not in terms of their relations to normative sources within specific religions, but rather in terms of their shared impulses to pursue certain projects and grievances. If we are to understand ways that mediated religious imaginaries function in contemporary politics, it is not necessary to pursue the normative constitution of those imaginaries in specific religions. Instead, Friedland urges us to think of these movements - in late modernity - as operating according to their own fungible, yet powerful sources of normative value, and that we should not be surprised to see consistency across cases.

For our purposes here, it is enough to draw from Friedland the notion that within the symbolic circulations of contemporary populisms (to the extent to which we can describe them as nationalist, and there is good reason to do so) we can expect to find symbolic and discursive resources drawn from religion, but now potentially deployed to secular political ends. They remain religiously nationalistic, but our task is to understand how those deployments work in a context of mediated imaginaries of religion and secularity.

\section{Conclusion: the Deployment of Mediated Religious Imaginaries}

My purpose in pursuing the various threads here is to point to a new analytical framing of the problem and the question of religion in modernity. These conditions suggest ways by which we might better understand the emerging discourses of religion and secularity in relation to global politics. As I have said, much of what we are seeing today seems incoherent or contradictory when 
viewed according to received categories of faith-based religion, interest-based politics and information-centered media. The deployment of imaginaries of religion and secularity in this politics seriously trouble these analytic frames. What we have seen here sets the context for a re-conceptualized analysis of relations between religion, secularity, media, and politics.

At the most basic level, we can see that the meanings and circulations through which we observe these social and political forces are much more partial and conditional than we are used to. Relations between religion and secularity, between structure and practice, between the concrete and the imagined, between symbol and referent, involve strategic deployments directed at particular ends, and it is through those ends that we understand the whole.

Reviewing a particular contemporary case will illustrate how my explorations here might be useful. As I said at the beginning, emergent neo-populist politics in Europe and North America has raised important challenges to politics. I noted that much of the discourse and symbolic exchange that defines these trends and movements seems to operate at the level of imaginaries, and that imaginaries of religion and secularity seem to be important symbolic sources. One of the most interesting cases in this neo-populist age is that of Russia and of the relationship between the Russian government of Vladimir Putin and the Russian Orthodox Church ${ }^{40}$. According to a number of sources, in recent years the church and Christianity have come to a more central place in the evolving political culture of Russia ${ }^{41}$. With the active involvement of both the Putin administration and the Orthodox leadership under Archbishop Kirill, church and state have come together in a project of common purpose.

What is fascinating about this development, though, are two features that are very relevant to what I've presented here. First (as is the case with a number of other national contexts I've reviewed), the normative center of this project of alliance is very much in line with what Friedland describes as the central tenets of religious nationalism in the twenty-first Century. The Putin/Kirill alliance is focused on a nostalgia for a lost past where Christian culture was definitive in Russia, it is focused on a certain neo-traditionalist vision of gender relations, and it is focused on once again "marking" Russian culture as specifically Christian. The second significant feature of the Russian situation is that much of the cultural "work" to bring this about is taking place at the level of imaginaries and imagination ${ }^{42}$. At the same time, these imaginaries are in the main deeply mediated.

$40 \quad$ Hersh 2018.

41 Hersh 2018; Ellis/Kolchyna 2017; Staehle, forthcoming.

42 Ellis/Kolchaya 2017, Staehle, forthcoming. 
For example, the evolving social and political discourse in Russia which centers this vision of the re-invigoration of Orthodoxy in (a still skeptical and largely secularized) public circulates through sources such as a television network called "Tsargradtv".43 Significant to my arguments here, this channel is often described as a mixture of American televangelism and the American political cable channel Fox News. The later connection is telling in that the senior producer of Tsargradtv came from Fox News, moving his family to Moscow and converting to Orthodoxy. The channel's programming is sophisticated and attractive, and it focuses on the three projects I describe above: nostalgia, traditionalist gender, and a re-centering of the church in a secularized Russia. It is important to my argument here that the Putin/Kirill relationship in fact involves some serious contradictions ${ }^{44}$. At the same time, on the level of media circulations and imaginaries, there is a seamlessness to it ${ }^{45}$. Putin's motivations for reaching out to the church are obvious, it helps him secure the support of particular constituencies in the Russian electorate. By invoking such symbols and normative values, even at a superficial level, he can strengthen his political base. Never mind that, beneath this level of imagination, Russia is also increasingly hostile to some religions, even Christian religions ${ }^{46}$.

Another, even more intriguing side of this story is how this emerging imaginary in Russia is making possible a revolution in relations between U.S. Evangelicals and both Russia and the Russian church $^{47}$. Where conservative Christians in the U.S. were once almost universally anti-Russian (a legacy of the secularism of the Soviet era), today there are strengthening links between them. Importantly, these links are not rooted in theology, but a shared imaginary of symbolic nostalgia, grievance, anxieties over evolving gender relations, and the desire to once again have Christianity at the center of culture. Operating on this level of imaginary, and through the actions of media such as Tsargradtv, these purposes and projects can be moved ahead.

How do we think about channels like Tsargradtv, or other media? The American political activist Steve Bannon is well-known for having come from a background of media production, both theatrical film and digital. His various productions also articulate the agenda of nationalism predicted by Friedland, and is seen in my analysis of cases like Tsargradtv. Both Tsargradtv and Bannon's productions owe much to the legacy of American Protestant media I discussed

\footnotetext{
43 Ellis/Kolchaya 2017.

44 Pertsev 2017.

45 Radio Free Europe 2018.

$46 \quad$ Moore 2019.

47 Burgess 2018.
} 
above. They fit into a long history of religiously-inflected media production focused on imagination and imaginaries of remembered and lamented pasts. I have begun to develop a way of thinking of such channels as "affective infrastructures" through which a moral economy of imaginative discourse is refined and circulated. Based in the ideas of Massumi ${ }^{48}$ and others, I'd suggest that one way of pushing ahead our understandings of mediated imaginaries of religion and secularity would be to understand how systems of mediation can do this sort of affective work. And it is on the level of affect that imagination and imaginaries of religion, politics, and societies can be perfected. It is the only context of such perfection. The contradictions of actually-existing relations of religion, society, and politics, work much less well together.

\section{Biography}

Stewart M. Hoover is Professor of Media Studies and Religious Studies at the University of Colorado at Boulder, where he directs the Center for Media, Religion, and Culture. He is an internationally-recognized expert on media and religion, and the University of Colorado's Center is one of only four in the world devoted to this important and emerging field of study. Professor Hoover has studied and written about televangelism, religion journalism, religion in secular and entertainment media, and religion in the internet and digital media. He has authored, co-authored, edited, or co-edited ten books, including Religion in the Media Age, Does God Make the Man: Media, Religion, and the Crisis of Masculinity (with Curtis Coats), and the edited volume, The Media and Religious Authority.

\section{Bibliography}

Alma, Hans/Vanheeswijck, Guido (ed.): Social Imaginaries in a Globalizing World. Berlin: DeGruyter, 2018.

Anderson, B.: Imagined Communities: Reflections on the Origin and Spread of Nationalism. London: Verso, 1991.

Asad, Talal: "The Construction of Religion as an Anthropological Category," in: Genealogies of Religion: Discipline and Reasons of Power ill Christianity and Islam. Baltimore: John Hopkins University Press, 1993 [1982], pp. 27-54.

48 Massumi 1995 . 
Balzell, Digby: The Protestant Establishment: Aristocracy and Caste in America. New Haven: Yale University Press, 1987.

Birnbaum, Michael/Timberg, Craig: "EU: Russians Interfered in Our Elections, Too," in: Washington Post, June 14, 2019. Available online: https://www.washington post.com/technology/2019/o6/14/eu-russians-interfered-our-elections-too/? noredirect=on\&utm_term=.7a0205673988 [accessed last on 22.07.2019].

Brubaker, Rogers: "Religion and Nationalism: Four Approaches," in: Nations and Nationalism 18 (1/2012), pp. 2-20.

Burgess, John P.: "The unexpected relationship between U.S. Evangelicals and Russian Orthodoxy," in: Christian Century, August 2, 2018. Available online: https://www. christiancentury.org/article/features/unexpected-relationship-between-usevangelicals-and-russian-orthodox [accessed last on 11.10.2019].

Calhoun, Craig/Jurgensmeyer, Mark/van Antwerpen, Jonathan (ed.): Rethinking Secularism. New York: Oxford University Press, 2011.

Campbell, Heidi: Digital Religion. London: Routledge, 2012.

Campbell, Heidi: "Surveying Theoretical Approaches within Digital Religion Studies", in: New Media \& Society 19 (1/2017), pp. 15-24.

Casanova, Jose: Public Religions in the Modern World. Chicago: University of Chicago Press, 1994 .

Couldry, Nick: Media, Society, World: Social Theory and Digital Media Practice. London: Polity Press, 2012.

Ellis, Bryan/Kolchyna, Viktoryia: "Putin and the Triumph of Christianity in Russia," in: Al Jazeera online, 19.10.2017. Available online: https://www.aljazeera.com/blogs/ europe/2017/10/putin-triumph-christianity-russia-171018073916624.html [accessed last on 22.07.2019].

Feder, J. Lester/Maplestone, Zorro: "The World Mourned When Notre Dame Burned. But Some Saw It As An Opportunity To Make France Catholic Again," in: Buzzfeed News, April 26, 2019. Available online: https://www.buzzfeednews.com/article/lesterfeder/notre-dame-fire-france-catholic-church-islam-mosques [accessed last on 22.07.2019].

Fessenden, Tracy: Culture and Redemption: Religion, the secular, and American literature. Princeton: Princeton University Press, 2006.

Friedland, Roger: "Money, Sex, and God: The erotic logic of religious nationalism," in: Sociological Theory 20 (3/2002), pp. 381-425.

Greenfield, Liah: Nationalism: Five Roads to Modernity. Cambridge: Harvard University Press, 1992.

Hendershot, Heather: Shaking the World for Jesus: Media and Conservative Evangelical Culture. Chicago: University of Chicago Press, 2004.

Hersh, Josh: "How Putin is using the Orthodox Church to build his power," in: Vice News, March 26, 2018. Available online: https://news.vice.com/en_us/article/ 
gymqgb/how-putin-is-using-the-orthodox-church-to-build-his-power [accessed last on 22.07.2019].

Hjarvard, Stig: "The mediatization of religion: A theory of the media as agents of religious change," in: Northern Lights 6 (1/2008), pp. 9-26.

Hollinger, David: After Cloven Tongues of Fire: Protestant liberalism in modern American history. Princeton: Princeton University Press, 2013.

Hoover, Dennis (ed.): Religion and American Exceptionalism. London: Routledge, 2014. Hoover, Stewart: Mass Media Religion: The social sources of the electronic church. Beverly Hills: Sage, 1987.

Hoover, Stewart: Religion in the Media Age. London: Routledge, 2006.

Horsfield, Peter: Religious Television: The American experience. Beverly Hills: Sage, 1984. Massumi, Brian: “The Autonomy of Affect," in: Cultural Critique 31 (3/1995), pp. 83-110. Mignolo, Walter: The Darker Side of Western Modernity: Global Futures, Decolonial Options. Durham: Duke University Press, 2011.

Mohn, Tanya: "Long before Twitter, Martin Luther was a media pioneer," in: New York Times, 28 October, 2016. Available online: https://www.nytimes.com/2016/10/30/ arts/design/long-before-twitter-martin-luther-was-a-media-pioneer.html [accessed last on 22.07.2019].

Moore, Rebecca: "Where is American Christian Outrage on Russia's treatment of Jehova's Witnesses?" in: Religion Dispatches, 26.02.2019. Available online: https:// rewire.news/religion-dispatches/2019/02/26/where-is-american-christian-outrageon-russias-treatment-of-jehovahs-witnesses/ [accessed last on 22.07.2019].

Morley, D./Chen, K.-H. (ed.): Stuart Hall: Critical dialogues in cultural studies. London/ New York: Routledge, 1996.

Mutz, Diana: "Status threat, not economic hardship, explains the 2016 vote," in: PNAS 115 (19/2018), pp. E4330-E4339.

Nyamnjoh, Francis: Drinking from the Cosmic Gourd: How Amos Tutuola can change our minds. Bamenda: Langaa RPCIG, 2017.

Orsi, Robert: "Everyday Miracles: The Study of Lived Religion," in: Lived Religion in America: Toward a History of Practice, ed. David Hall, Princeton: Princeton University Press, 1997.

Pertsev, Andrey: "President and Patriarch: What Putin Wants from the Orthodox Church," Carnegie Moscow Center, 19.12.2017. Available online: https://carnegie.ru/ commentary $/ 75058$ [accessed last on 10.10.2019].

Radio Free Europe: "Putin Hails 'Eternal Christian Values' Amid Orthodox Christmas Celebrations,” 6.01.2018. Available online: https://www.rferl.org/a/putin-christmasrussia-berlarus-georgia-kazakhstan-macedonia-moldova-serbia-ukrainearmenia/28959952.html [accessed last on 11.10.2019].

Romanowski, William: Reforming Hollywood: How Protestants fought for freedom at the movies. New York: Oxford University Press, 2012. 
Roof, Wade Clark: Spiritual Marketplace: Baby boomers and the remaking of American religion. Princeton: Princeton University Press, 1998.

Smith, Anthony: Chosen Peoples: Sacred sources of national identity. New York: Oxford, 2004.

Staehle, Hanna: Media and Religion in Russia: How digital criticism is driving transformation of the Russian Orthodox Church. London: Routledge, forthcoming.

Stolow, Jeremy: "Religion and/as Media," Theory, Culture \& Society 22 (4/2005), pp. 119-145.

Warner, R. Stephen: "Work in Progress Toward a New Paradigm for the Sociological Study of Religion in the United States," in: American Journal of Sociology 98 (5/1993), pp. 1044-1093. 